\title{
Alleviating Anxiety Through the Abecedarian: On Supporting New Doctoral Students
}

\author{
Amber Moore
}

\begin{abstract}
This paper seeks to offer insights and gentle suggestions for higher education leaders, particularly those teaching and supervising new doctoral students. Graduate students experience stress and anxiety, making entering the academic sphere an often emotionally taxing move. In response, a great deal of research examines how university faculty might ease this transition into a particularly intimidating, rigorous space. As such, this poetic offering invites education leaders who interact with new doctoral students to consider an abecedarian written in the spirit of capturing the potential needs and wants of early scholars navigating their PhD programs at the beginning of the journey.
\end{abstract}

\section{On the Anxiety and Anguish of Starting Graduate Work}

I entered graduate school somewhat naively; like many fellow students, "The dreams of a magnificent future [lay] before [me], and [I could] almost touch the majesty" (Di Pierro, 2017, p. 24). However, during the first year of my PhD program studying language and literacy education, rather than basking in "majesty," I was tormented by anxiety. It was a layered, painful experience, which I have spent considerable time reflecting on; I've struggled with both imposter syndrome (Moore, 2018a), and learning about the importance of humility and self-care during a PhD journey (Moore, 2018b). Unfortunately, my struggle is not unique; much recent scholarship has demonstrated that anxiety, stress, and depression are common among university students (Bazrafkan, Shokrpour, Yousefi, \& Yamani, 2016). In fact, graduate students are notorious for mental health struggles (see, for example, Baptista, 2013; Bazrafkan et al., 2016; Brown, 2013; Di Pierro, 2017; Swartz \& Kay, 2009). One student in Bazrafkan and colleagues' (2016) study admitted, "I had never experienced so much stress and anxiety in all my life. All systems of my body were disturbed. I was always crying because, I felt... I'm dying" (p. 236).

Many refer to this common problem as the "campus mental health crisis" (Swartz \& Kay, 2009). As such, with this paper, I aim to turn my attention to how early scholars' experiences might inform established scholars who interact with graduate students, especially as either their course work instructors and/or supervisors and members of their doctoral committees. How new doctoral students are attended to by seasoned scholars is significant, particularly through mentoring (see, for example, Cumings Mansfield, Welton, \& Young, 2010; Gammel \& Rutstein-Riley, 2016; Holdaway, Deblois, \& Winchester, 1995; Mullen, Fish, \& Hutinger, 2010; Pidgeon, Archibald, \& Hawkey, 2014; Yob \& Crawford, 2012); as Felder (2010) asserts, "Doctoral student development... is a process where faculty members can have tremendous influence to enhance the likelihood of success" (p. 455). 
Strategies such as empathetic mentorship are important, and so, I offer an invitation to education leaders in postsecondary institutions who interact with new doctoral students to consider an abecedarian written in the spirit of capturing the potential needs and wants of those navigating the early stages of their PhD programs.

\section{A Case for a Poetic Inquiry Into Graduate Anxiety}

Many faculty members in higher education interact with and influence graduate students daily. From program directors to teaching professors, academics play significant and varied roles. While this poetic inquiry is aimed to help provide insight for individuals in all the different supporting roles, particularly for new doctoral students, perhaps the supervisory role is the most impactful, and as such, this project is especially geared towards these leaders. According to Watts (2008), "The supervisor is understood to be the academic assigned to guide the doctoral student in all aspects of the research process; the extent to which this will also involve pastoral care of the student will differ across institutions" (p. 370). However, she goes on to acknowledge that within this dynamic, "it is reasonable to expect some element of empathy work" (p. 370). Empathy is "the capacity to think and feel oneself into the inner life of another person" (Kohut, 1984, as cited in Evans, 2016, p. 44), and such potential empathy is the central component being explored in this poetic inquiry with its power to begin the process of "connect[ing] empathetically and understand[ing]... complex psychosocial processes" (McCulliss, 2013, p. 84). As such, how an established academic might exercise an ethic of care and consideration when entering into either an interaction with or a relationship with a doctoral student will be explored. Poetic inquiry is used as a dynamic methodology to employ chiefly because it espouses "living poetically" (Leggo, 2005) and offers potential for fostering well-being and emphasizes the transformative power of exercising empathy while investigating lived experiences.

Poetic inquiry is understood to be a number of different things at the same time; Prendergast (2009) has chronicled its vastness, uncovering 40 different terms that describe it and three central categories of the methodology: vox theoria, vox autobiographia/autoethnographia, and vox participare. For the purposes of this paper, this poetic inquiry belongs to the category of vox theoria, "poems [that are] inquiry itself" (Prendergast, 2009, p. xxii). With this vox theoria inquiry, I especially follow in Leggo's (2005) example, and am inspired by his use of poetic inquiry as a means to ruminate on "the poetic possibilities for conceiving and fostering the wellbeing of teacher [candidates]" (p. 440). Within the field of education, many researchers use poetic inquiry to explore dynamics of learning (see, for example, CahnmannTaylor, 2009; Gorlich, 2016; Meyer, 2008; Patrick, 2016; Prendergast, Gouzouasis, Leggo, \& Irwin, 2009; Wiebe \& Margolin, 2012; Wiebe, Snowbar, \& Walsh, 2017, just to name a few), demonstrating that particularly in education research, "we should always be looking for new rhetorics," promoting "the utility and value of poetry as a dynamic rhetoric for educational research and practice" (Leggo, 2005, p. 443). In doing such work, Leggo describes the power of "living poetically," and like his concern for Bachelor of Education students, I am similarly concerned for new doctoral students, and am curious about what seasoned academics can do for them. Poetic inquiry is especially appropriate for 
investigating issues of support and mentorship because ultimately, poetry as "an intentional process can help... the audience of the poems to reach praxis or the process of being moved to action, to affect change, and to better the next experience [my emphasis]" (Killingsworth Roberts, Brasel, \& Crawford, 2014 , p. 168). Poetry "presents, and is a catalyst for, a window into the heart of the human experience" (McCulliss, 2013, p. 83). It is exactly this window of experience(s) that I attempt to tap into here; through the abecedarian poetic inquiry, I wish to tap at 26 "windows" as possible entry points for insight and understanding in the graduate school experience because like Wiebe and Margolin (2012), I also found that, in "each moment of looking back... a new moment of understanding" (p. 28) emerged. Perhaps by exploring this abecedarian, more seasoned academics might remember, or gain new knowledge about, how some students might be coping with their early time in academia.

\section{"A" Is for Anxiety: The Abecedarian as a Poetic Entry Point}

The abecedarian, a poetic form using the alphabetic sequence as a formal structure, also known as an abecedarium, abecedary, or alphabet acrostic (Ardam, 2014, p. 138), was introduced to me by Carl Leggo during a course on theory and research in the teaching of written composition in my language and literacy education PhD program. He suggested this poetic form as a method for reflecting on the endless ways to think about text and recognize emerging forms. For example, he described the "movel," a book written after the film, as one he had just learned of (Dr. C. Leggo, personal communication, September 21, 2016). Then, he instructed us to write collaborative abecedarians as a way to poetically and generatively engage with thinking about text. My first thought? " $A$ " is for "anxiety."

As mentioned, my first year as a PhD student was marked with overwhelming fear and stress. Much like one of my favourite poets, Sharon Olds (1996) chronicles in her piece, "Early abecedarian," I also felt like "each day, I tried to read/ the world" (p. 121) of academia to find my place. Having to work with my peers, all of whom I was certain were far more intelligent and capable than myself, was certainly anxiety inducing. During the activity Dr. Leggo set out for us, I immediately offered to be the "recorder" to write the poem as we worked, in order to contribute without actually having to say too much. As the poem formed, A through Z, about all kinds of texts—epitaphs, fragments, guerrilla poetry, tweets, utterancesI realized the constraint of the abecedarian was comforting; this poem felt like a useful tool to "find words 'that work'" (Galvin \& Todres, 2009, p. 311).

Although Cooley (2014) writes in "At the window": "what could be worse/ than to begin with "A"" (p. 5), this poetic inquiry begins with $\mathrm{A}$ to offer an abecedarian on how higher educators might access entry points in an effort to artfully contribute to scholarship on supporting graduate students. For this poetic inquiry, I draw from a number of personal texts I wrote in the first year of my PhD, including my journal, personal calendar, to-do lists, and text messages where I was discussing my school experiences. Like Piirto (2002), "As a writer, I have kept... personal journals, which could, in the lingo of qualitative research, be construed as field notes" (p. 436). I mined these texts to remind myself of moments where I was learning about my wants and needs as a student, and reflected on a variety of best practices that leaders around me employed to help me feel supported and welcomed. In this way, I hope that this poem 
"allows the heart to lead the mind rather than the reverse" (Butler-Kisber \& Stewart, 2009, p. 3), as I put forward a heartfelt offering of poetic experiences that might help inform academics on some of what novice academics might be yearning for.

\section{An Abecedarian for Alleviating Anxiety}

An anecdote, please, right away. Our hearts are beating; sweat is beading behind the hairlines, slipping down our backs like children inching away from strangers, returning to safety behind their mother's legs. At first, we might want to be seen and not heard; we stammer, laugh too loudly, and it rushes out in embarrassing bursts, smelling like our third coffee. Share an early story about your academic beginnings, or better yet- missteps. Give us time to calm down and suck a Mentos.

Be present, if you can. We notice when you're distracted by emails, texts from your kid asking for a ride home later, or your growling stomach; it's 3pm and you haven't touched that damp egg salad sandwich that's crouching at the bottom of the beach bag you now use as a purse. You're clearly so accomplished and so busy, but just know that we re-wrote the email to set up this meeting four times. Our partner yelled at us when we asked (again) which closing salutation to use: "Best care"? "Warm regards"? "Warmly"? Bleary-eyed and dangerously precoffee, we have been stared at with an incredulous expression and asked when did you become so damn insecure? So please, eat that sandwich in front of us and remember that we are attuned to everything you do. You are our academic hero.

Curtail expectations. We do not exactly know what the hell we're doing here. Some of us came because we were scared of living with ourselves if we had not gone for it. It got morbid, thinking about how we would feel if we were at the end of our life and filled with regret for staying a high school English teacher two decades too long because it was safe, with a nice pension. We worried that teaching Macbeth dozens of times might make us hate Shakespeare like the kids do, that we would become one of those bitter shells in the staff room bitching about teenagers over stale jelly doughnuts. We don't have it all figured out yet even though we're not that young anymore, but we did realize that we want to demand more of ourselves. We're excited about where that fire might take us, and you're fanning our flames. Thank you for that.

Do not bother reviewing the syllabus in great detail during our first class. We read it very carefully before we even signed up. Just ask if we have questions - that is where the magic is.

Evade requests for extensions. This might be in your practice already. We need deadlines like:
a. A millennial needs a good job with benefits.
b. Hillary needs a rage room.
c. Trump needs to disable Twitter.
d. And so on. 
Foster a community with us - an "intellectual community of practice" (Stroude et al., 2014, p. 44). Invite colleagues in to guest lecture our courses; we especially love seeing academic friendships on display, so haul in that brilliant feminist scholar that you play racquetball with twice a month. Brief them on our research interests and make sure they are happy to open their office doors to us too. Use us like a talking stick and gently encourage us to blossom unless, of course, we are cocky. Nip that in the bud.

Goal-set with us. It is a productive and poetic practice; Emily Dickinson writes: "in every human nature/ a goal,/ admitted scarcely to itself," describing goals as a kind of "brittle heaven" (Dickinson as cited in Petrino, 2001, p. 138). "Brittle" is an excellent characterization of many graduate students, so engaging us in a transparent chat about your practice with teaching and supporting us is helpful:

It is... critical that faculty members look introspectively into their advising processes to ensure that they are humane, timely, efficient, productive, compassionate, and encouraging - while at the same time, safeguarding academic integrity and standards.

(Di Pierro, 2017, p. 26)

Have a meeting with us in a coffee shop. Our blood already has concerning caffeine content and who does not want an earl grey and lavender muffin while discussing a reach-for-the-stars research grant? As Hemer (2012) suggests:

Cafés can be seen as a 'third place' and in this capacity lend supervisory meetings a neutral and levelling atmosphere. Supervision over coffee is consistent with newer models or styles of supervision, which emphasise mentoring and collaboration rather than expert-disciple models. (p. 836)

Further to this point, Sameshima (2017) writes in her poem about "how to become a better learner and maker of love" - that is, a "seeking [of] relation and understanding" (p. 147) - the following:

HIGH BID 5: My Mentor

My mentor eats with me in the same place we've met

For more than a decade - a place others meet with him

He gives me a lift, lifts my work, and holds my words

Sameshima's speaker goes on to describe how they are "in love," and while we don't want this with you, we could definitely go for some of this lovely lifting and holding of words business.

If we are part-time, we are fully stressed; we have "fractured" student identities (Watts, 2008, p. 369). 
Joke around a little bit or get catty about a grand theorist we are intimidated by. Tell us about that time you met that scholar who largely factored into your own dissertation; shake your head and warn us, "never meet your heroes." He was fifteen minutes late to his own keynote and was "a real ass" when you scored a few moments one-on-one. Describe how you flinch when you have no choice but to cite him now. Dark humour will go over well. Remember this question: "Are you a mentor? Or do you do mentoring?" (Barcus \& Crowley, 2012, p. 75).

Kindly, tell us to put our goddamn phones away during class.

Lie selectively about items such as: how much sleep you get, how cruel reviewers can be, optimism and job prospects, and all lights at the ends of all tunnels.

Manage our expectations. Faculty who interact with us, particularly our advisors, "evaluate[] and uphold[] the academic bar of the doctoral degree" (Gammel \& Rutstein-Riley, 2016, p. 28). No, we will not get that grant. Yes, this draft needs a lot of work. Unfortunately, that journal does not value arts-based research as much as it should - they are just not there yet. When no one comes to your conference presentation, remember it's because it was scheduled during lunch, where they are serving sliders - sliders!

Notice: dark/bloodshot/glassy/empty eyes. Notice the too early/too late hours we send emails. Notice the title of the first publication that we send out for review because we agonized over it. Notice our progress. Notice our chewed, picked over and bloody fingernails. Notice significant weight loss and gain. Notice pill bottles that fall out of our bags when we dig for a pen. Notice if we stop mentioning our partners. Notice if we look pregnant but avoid staring; as Squillante (2008) describes of teaching as a pregnant graduate student: "They watch my belly every Monday, Wednesday, and Friday from 11:15 to 12:05" (p. 20). How unsettling is that.

Offer us opportunities to take a closer look at how you work and who you are as an academic. What are your writing habits? How do you handle rejection? Do you use iCal or do post-its bloom on the walls of your home office? Do you kick box? Do you drink green tea? Are you a foodie? How do you get yourself to the place where you do what you do as an expert in the field - all the stuff other than reading heaps of expensive books? Remember that "cross sharing elements of one's personal life, opinions, and activities between mentees and mentors is not only condoned, it is encouraged" (Yob \& Crawford, 2012, p. 44).

Pay close attention to international students. As Cree (2012) recalls:

When this student arrived from Bangladesh, he initially had neither a computer nor a desk to sit at (although both are routinely provided to PhD students, they were not immediately available to him). I was not one of his designated supervisors, but I was aware that he was 
hanging about the office, unhappy and insecure. I had recently bought a new computer, so I offered him my old computer. I then helped him to get settled at a desk. This all seemed a tiny amount of support on my part, but was hugely important to him. He brought me a gift the next day... (p. 456).

Question the nature of academic discourse alongside us. For example, Paré (2017) pointedly/poignantly asks: "... is the academy stuck on single-authored, print-based texts while the rest of the world has gone collaborative and digital?" (p. 408). Rebel with us.

Recognize our differences and honour them. A few items to see and understand include:

- "racial and ethnic differences... exist in the presentation of mental health problems and the utilization of mental health services" (Hyun, Quinn, Madon, \& Lustig, 2006, p. 249);

- "ethnic minority students usually more sensitized to a lack of respect and to microaggressions and are in a very vulnerable position to be able to speak up in the moment" (Barcus \& Crowley, 2012, p. 76). In fact, many describe their academic environment as a "chilly climate" (Boyer \& Butner, 2011, p. 32). For instance, Felder (2010) asserts, "For many African American doctoral students, progress towards a degree completion is a journey wrought with obstacles" (p. 455). Ethnic minority students also represent understudied groups in terms of experiences in higher education; as an example, only "a few scholars have drawn attention to Latina educational needs and experiences along the academic life course" (Espino, 2016, p. 186);

- "IIndigenous graduate students] usually do not have mentorship or guidance from an Indigenous faculty member or ally" (Pidgeon et al., 2014, p. 3):

- like ethnic minority students, LGBTQ students also "typically endure microassaults" and "microinsults" (Hawley, 2015, p. 3);

- "higher education professionals are in a unique role to help open doors to opportunity for students with disabilities by providing them with accepting, supportive, and life-changing environments that help them thrive" (Cimini, 2017, p. 44); and

- "for women at the beginning of their doctoral studies, mentoring must be flexible and take into consideration aspirations, fears, experiences, and expectations of young researchers" (Stroude et al., 2015, p. 49).

And so on. Our differences are important and significantly inform our experiences at the university so being mindful of this while you support us is so appreciated. Thank you.

Start writing with us, if you can. We know that we need to start publishing, like, yesterday. Alvarez, Bonnet, and Kahn (2014) argue that the "publish or perish" dilemma "proves to be just as resonant and anxiety-provoking for graduate students who plan to [enter] academia" (p. 2) as it is for faculty members. However, if we write alongside experts like you, we will be in so much better shape. 
Take us outside for a class or meeting. After all, "there are many commonalities between graduate school and packing it into the wilderness" (Barcus \& Crowley, 2012, p. 78). Sit us down in the campus rose garden or under an oak older than both of our ages combined. A bench will do but cross-legged on the grass would be epic. Initial small talk about the weather goes over better here because we can feel it. If you're really in a generous mood, let's go for a walk in the woods; apparently forest bathing, or Shinrin-yoku (Tsunetsugu, Park, \& Miyazaki, 2010) is good for heart health (see, for example, Ideno et al., 2017; Li et al., 2016; Mao et al., 2017; Yang et al., 2016).

Upgrade your software. We should ensure we are digitally compatible so that we both don't want to pull out our hair (assuming we have any at this point in our lives). How long does it take to get this $\mathrm{PhD}$ anyway? We age decades in a year here - our hair is thinning.

Validate our feelings when we:

a. cry in front of you;

b. Actually, that's all. This will be a humiliating moment(s) for us. Throw us a bone even though we really need to pull it together - now. We are biting our lip bloody. We know that we need to act more professionally, but Foucault has trampled our spirit somewhat lately. Or Vygotsky. Or Derrida. Hell, all of them. They did a little dance and left mud everywhere, staining us. Have mercy.

Watch for an ambivalent attitude - we are not like that. We care too much not too little. Something must be up.

$\mathbf{X}$ - out some time in your schedule to attend any of our first presentations, if you can make it. Maybe we are participating on a panel discussion, giving a talk at our department graduate symposium, or we are brave enough to 'dance our PhD,' or train ourselves for the 3MT - the dreaded three-minute thesis competition for some extra cash to spend on Amazon Prime. Especially if you have encouraged us to apply, or wrote a reference for us, please show up early on - you will likely be one of three faces we know in the crowd. And you will not throw us a hardball question either - will you? Please do not. X that out too. Save those questions for the defence, at the end of the road.

Yes, we need to talk money. It is (likely) our constant concern; we live in expensive rentals near the university with horrendous landlords who have more money than morals. Wedding invitations are sweat-inducing. Can I wear a dress I already own? How many people that will be there have already seen me in said dress? Will it fit anymore? Damn those campus cinnamon buns. When we wine-shop, we check two numbers: (1) the alcohol content and (2) the price, expecting a 'robust' relationship between them both. Opening up space for us to have an open and honest dialogue about dollars is healthy and necessary because "literature 
Alleviating Anxiety Through the Abecedarian: On Supporting New Doctoral Students

on financial support for graduate students is limited" (Boyer \& Butner, 2011, p. 23), so we do not even have any peer-reviewed opinions to peruse.

Zone out from our progress regularly. We have to be able to stand alone sometimes and you are busy as hell. We get that. Actually, we do not; we do not have any real grasp on what it is like being a working professor. The pressures must be endless. We need to operate like we are last on your list; often, we might have to be. And that is okay too. Thank you for having us on your list at all - we are thrilled to be under your wing.

\section{References}

Alvarez, B., Bonnet, J. L., \& Kahn, M. (2014). Publish, not perish: Supporting graduate students as aspiring authors. Journal of Librarianship \& Scholarly Communication, 2(3), 1-12.

Ardam, J. (2014). The ABCs of conceptual writing. Comparative Literature Studies, 51(1), 132-158.

Baptista, A.V. (2013). 'With all my heart': Mature students' emotions while doing a research-based PhD. Procedia - Social and Behavioural Sciences, 114, 914-918.

Barcus, C. G., \& Crowley, S. L. (2012). Training ethnic minority graduate students in a white man's program: Don't get bucked off! Journal of Multicultural Counselling and Development, 40(2), 70-81.

Bazrafkan, L., Shokrpour, N., Yousefi, A., \& Yamani, N. (2016). Management of stress and anxiety among PhD students during dissertation writing: A qualitative study. The Health Care Manager, 35(3), 231-240.

Boyer, P. G., \& Butner, B. (2011). Advancing or hindering the next generation? A look at financial aid for minority graduate students. Journal of Student Financial Aid, 41(2), 22-35.

Brown, P. (2013). Loneliness at the bench: Is the PhD experience as emotionally taxing as it is mentally challenging? European Molecular Biology Organization, 14(5), 405-409.

Butler-Kisber, L., \& Stewart, M. (2009). The use of poetry clusters in poetic inquiry. In M. Prendergast, C. Leggo, \& P. Sameshima (Eds.), Poetic inquiry: Vibrant voices in the social sciences (pp. 3-12). Rotterdam, The Netherlands: Sense Publishers.

Cahnmann-Taylor, M. (2009). The craft, practice, and possibility of poetry in educational research. In M. Prendergast, C. Leggo, \& P. Sameshima (Eds). Poetic inquiry: Vibrant voices in the social sciences (pp. 13-30). Rotterdam, The Netherlands: Sense Publishers.

Cimini, M. D. (2017). Understanding disability: The psychological and sociocultural experience. In D. S. Anderson (Ed.), Further wellness issues for higher education: How to promote student health during and after college (pp. 41-58). New York, NY: Taylor \& Francis.

Cooley, D. (2014). Abecedarium. Canada: University of Alberta Press.

Cree, V. E. (2012). 'I'd like to call you my mother': Reflections on supervising international PhD students in social work. Social Work Education, 31(4), 451-464. 
Cumings Mansfield, K., Welton A., L, P. L., \& Young, M. D. (2010). The lived experiences of female educational leadership doctoral students. Journal of Educational Administration, 48(6), 727-740.

Di Pierro, M. (2017). Mental health and the graduate school experience. The Journal for Quality \& Participation, 40(1), 24-27.

Espino, M. M. (2016). "Get an education in case he leaves you": Consejos for Mexican women PhDs. Harvard Educational Review, 86(2), 183-205.

Evans, K. (2016). A/R/T(therapist)-ography: Examining the weave. In K. T. Galvin \& M. Prendergast (Eds.), Poetic Inquiry II - seeing, caring, understanding: Using poetry as and for inquiry (pp. 41-50). The Netherlands: Sense Publishers.

Felder, P. (2010). On doctoral student development: Exploring faculty mentoring in the shaping of African American doctoral student success. The Qualitative Report, 15(2), 455-474.

Galvin, K., \& Todres, L. (2009). Poetic inquiry \& phenomenology research: The practice of 'embodied interpretation.' In M. Prendergast, C. Leggo, \& P. Sameshima (Eds.), Poetic inquiry: Vibrant voices in the social sciences (pp. 307-316). The Netherlands: Sense Publishers.

Gammel, J., \& Rutstein-Riley, A. (2016). A relational approach to mentoring women doctoral students. New Directions for Teaching and Learning, 147, 27-35.

Gorlich, A. (2016). Poetic inquiry: Understanding youth on the margins of education. International Journal of Qualitative Studies in Education, 29(4), 520-535.

Hawley, J. C. (2015). Expanding the circle: Creating an inclusive environment in higher education for LGBTQ students and studies. Albany, NY: State University of New York Press.

Hemer, S. R. (2012). Informality, power and relationships in postgraduate supervision: Supervising PhD candidates over coffee. Higher Education, Research, and Development, 31(6), 827-839.

Holdaway, E., Deblois, C., \& Winchester, I. (1995). Supervision of graduate students. Canadian Journal of Higher Education, 25(3), 1-29.

Hyun, J. K., Quinn, B. C., Madon, T., \& Lustig, S. (2006). Graduate student mental health: Needs assessment and utilization of counselling services. Journal of College Student Development, $47(3), 247-266$.

Ideno, Y., Hayashi, K., Abe, Y., Ueda, K., Iso, H., Noda, M., et al. (2017). Blood pressure-lowering effect of Shinrin-yoku (Forest bathing): A systematic review and meta-analysis. BMC Complementary and Alternative Medicine, 17, 1-12.

Killingsworth Roberts, S., Brasel, N. A., \& Crawford, P. A. (2014). Poetry as praxis: An exploration of poetry discourse as qualitative inquiry. Journal of Poetry Therapy, 27(4), 167-181.

Leggo, C. (2005). The heart of pedagogy: On poetic knowing and living. Teachers and Teaching: Theory and Practice, 11(5), 439-455.

Leggo, C. (2016). Lecture(s) on theory and research in the teaching of written composition. Personal collection of author. University of British Columbia, Vancouver, BC. 
Alleviating Anxiety Through the Abecedarian: On Supporting New Doctoral Students

Li, Q., Kobayashi, M., Kumeda, S., Ochiai, T., Miura, T., Kagawa, T., et al. (2016).

Effects of forest bathing on cardiovascular and metabolic parameters in middle-aged males.

Evidence-Based Complementary and Alternative Medicine, 2016, 1-8.

Mao, G., Cao, Y., Wang, B., Chen, Z., Wang, J., Xing, W., et al. (2017). The salutary influence of forest bathing on elderly patients with chronic health failure. International Journal of Environmental Research and Public Health, 14, 368-383.

McCulliss, D. (2013). Poetic inquiry and multidisciplinary qualitative research. Journal of Poetry Therapy, 26(2), 83-114.

Meyer, E. J. (2008). "Who we are matters": Exploring teacher identities through found poetry. LEARNing Landscapes, 2(1), 195-210.

Moore, A. (2018a). "Blackboxing it": A poetic min/d/ing the gap of an imposter experience in academia. Art/Research International: A Transdisciplinary Journal, 3(1), 30-52.

Moore, A. (2018b). Eight events for entering a PhD: A poetic inquiry into happiness, humility, and selfcare. Qualitative Inquiry, 24(8), 592-596.

Mullen, C. A., Fish, V. L., \& Hutinger, J. L. (2010). Mentoring doctoral student through scholastic engagement: Adult learning principles in action. Journal of Further and Higher Education, 34(2), 179-197.

Olds, S. (1996). Early abecedarian. Salmagundi, 112(fall), 121.

Paré, A. (2017). Rethinking the dissertation and doctoral supervision / Reflexiones sobre la tesis doctoral y su supervisión. Infancia y Aprendizaje, 40(3), 407-428.

Patrick, L. D. (2016). Found poetry: Creating space for imaginative arts-based literacy research writing. Literacy Research: Theory, Research, and Practice, 65, 384-403.

Petrino, E. (2001). Nineteenth-century American women's poetry. In D. M. Bauer \& P. Gould (Eds.), The Cambridge companion to nineteenth-century American women's writing (pp. 122-140). New York, NY: Cambridge University Press.

Pidgeon, M., Archibald, J., \& Hawkey, C. (2014). Relationships matter: Supporting Aboriginal graduate students in British Columbia, Canada. Canadian Journal of Higher Education, 44(1), 1-21.

Piirto, J. (2002). The question of quality and qualifications: Writing inferior poems as qualitative research. International Journal of Qualitative Studies in Education, 15(4), 431-445.

Prendergast, M. (2009). Introduction: The phenomenon of poetry in research: "Poem is what?" Poetic inquiry in qualitative social science research. In M. Prendergast, C. Leggo, \& P. Sameshima (Eds.), Poetic inquiry: Vibrant voices in the social sciences (pp. xix-2). Rotterdam, The Netherlands: Sense Publishers.

Prendergast, M., Gouzouasis, P., Leggo, C., \& Irwin, R. (2009). A haiku suite: The importance of music making in the lives of secondary students. Music Education Research, 11(3), 303-317.

Sameshima, P. (2017). Enchanting "love-making." In P. Sameshima, A. Fidyk, K. James, \& C. Leggo (Eds.), Poetic inquiry: Enchantment of place (pp. 147-150). Wilmington, DE: Vernon Press. 
Squillante, S. (2008). Student/body. In E. Evans, C. Grant, \& M. Peskowitz (Eds.). Mama, PhD (pp. 20-24). New Brunswick, NJ: Rutgers University Press.

Stroude, A., Bellier-Teichmann, T., Cantero, O., Dasoki, N., Kaeser, L., Ronca, M., et al. (2015). Mentoring for women starting a PhD: A "free zone" into academic identity. International Journal for Mentoring and Coaching in Education, 4(1), 37-52.

Swartz, V., \& Kay, J. (2009). The crisis in college and university mental health. Psychiatric Times, 26(10), 32 .

Tsunetsugu, Y., Park, B-J., \& Miyazaki, Y. (2010). Trends in research related to "Shinrin-yoku" (taking the forest atmosphere or forest bathing) in Japan. Environmental Health and Preventative Medicine, 15(1), 27-37.

Watts, J. H. (2008). Challenges of supervising part-time PhD students: Towards student-centred practice. Teaching in Higher Education, 13(3), 369-373.

Wiebe, S. \& Margolin, I. (2012). Poetic consciousness in pedagogy: An inquiry of contemplation and conversation. In Education, 18(1), 23-36.

Wiebe, S., Snowbar, C., \& Walsh, S. (2017). Curriculum triage: A poetic play upon crisis in schools. In P. Sameshima, A. Fidyk, K. James, \& C. Leggo (Eds), Poetic inquiry: Enchantment of place (pp. 337-346). Wilmington, DE: Vernon Press.

Yang, B. B., Mao, Z. X., Lyu, G. X., Wen, Y. D., Xu, X. L., Lyu Xiao, W. H., et al. (2016). Health effect of forest bathing trip on elderly patients with chronic obstructive pulmonary disease. Biomedical and Environmental Sciences, 29(3), 212-218.

Yob, I. M., \& Crawford, L. (2012). Conceptual framework for mentoring doctoral students. Higher Learning Research Communications, 2(2), 34-47.

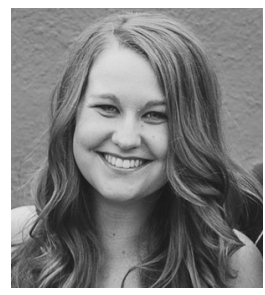

Amber Moore is a SSHRC-funded PhD candidate and Killam Laureate at the University of British Columbia studying language and literacy education with the Faculty of Education. Her research interests include adolescent literacy, feminist pedagogies, teacher education, and trauma literature, particularly YA sexual assault narratives. She also enjoys writing poetry and creative nonfiction. 